\title{
FUNGSI SINTAKTIS DAN PERAN SEMANTIS ARGUMEN INTI BAHASA MANGGARAI DIALEK MANGGARAI TENGAH ${ }^{1}$
}

\author{
Albertina Yosefina Samu ${ }^{2}$ \\ Prodi Linguistik, Pascasarjana Universitas Nusa Cendana
}

\begin{abstract}
This study examines the syntactic functions and the semantic roles of core arguments in Central Manggarai Dialect of Manggarai Language (CMDML). There are two theories applied in this study, i.e., Lexical- Functional Grammar and Macro Roles. This research uses qualitative method. The source of data is Manggarai language texts in oral and written forms. The results show that the basic structure of verbal clauses in CMDML are $\mathrm{S}+\mathrm{P}+\mathrm{O}, \mathrm{P}+\mathrm{O}+\mathrm{S}, \mathrm{S}+\mathrm{P}+\mathrm{O}+\mathrm{O}_{\theta}, \mathrm{S}+\mathrm{P}+\mathrm{COMP}, \mathrm{P}+\mathrm{COMP}+\mathrm{S}, \mathrm{P}+\mathrm{S}+\mathrm{COMP}$ and nonverbal clauses are $\mathrm{S}+\mathrm{P}, \mathrm{P}+\mathrm{S}$. The syntactic functions of core arguments in CMDML are Subject (SUBJ), Object (OBJ) and Object Teta $\left(\mathrm{OBJ}_{\theta}\right)$. The semantic roles of core argument in CMDML are devided into two, macroroles and thematic roles. Macroroles consist of Actor and Undergoer, while thematic roles consist of Agent, Experiencer, Effector, Recipient, Theme, Source dan Patient.
\end{abstract}

Keywords: Manggarai language, syntactic function, semantic roles

\begin{abstract}
Abstrak
Penelitian ini mengkaji tentang fungsi sintaktis dan peran semantis argumen inti bahasa Manggarai Dialek Manggarai Tengah (BMDMT). Teori yang digunakan adalah tatabahasa Leksikal-Fungsional dan peran makro. Penelitian ini menggunakan metode kualitatif. Sumber data berupa teks lisan dan teks tertulis bahasa Manggarai. Hasil penelitian menunjukkan bahwa struktur dasar klausa verbal BMDMT adalah $S+P+O$, $\mathrm{P}+\mathrm{O}+\mathrm{S}, \mathrm{S}+\mathrm{P}+\mathrm{O}+\mathrm{O}_{\theta}, \mathrm{S}+\mathrm{P}+\mathrm{Ket}, \mathrm{P}+\mathrm{Ket}+\mathrm{S}, \mathrm{P}+\mathrm{S}+\mathrm{Ket}$ dan klausa nonverbal adalah $\mathrm{S}+\mathrm{P}$, $\mathrm{P}+\mathrm{S}$. Fungsi sintaktis argumen inti dalam BMDMT adalah subjek (SUBJ), objek (OBJ), dan objek teta $\left(\mathrm{OBJ}_{\theta}\right)$. Peran semantis argumen inti dalam BMDMT terdiri atas peran makro dan peran tematis. Peran makro terdiri atas Actor dan Undergoer, sedangkan peran tematis terdiri atas Agen (Agent), Pengalam (Experiencer), Pemengaruh (Effector), Penerima (Recipient), Tema (Theme), Sumber (Source), dan Penderita (Patient).
\end{abstract}

Kata Kunci: bahasa Manggarai, fungsi sintaktis, peran semantis

\section{LATAR BELAKANG}

Bahasa Manggarai (selanjutnya disebut BM) merupakan salah satu bahasa dari rumpun bahasa yang berada dalam cakupan Austronesia. Bahasa Manggarai digunakan oleh 600.000 orang Manggarai dengan beberapa varian dialek di dalamnya antara lain dialek Manggarai Barat, Manggarai Tengah, dan Manggarai Timur. Pengguna BM tersebar di tiga kabupaten, yakni Manggarai Timur, Manggarai, dan Manggarai Barat. Manggarai merupakan salah satu kabupaten yang terletak di Flores Barat. Secara administratif, kabupaten ini berada di Provinsi Nusa Tenggara Timur. Secara geografis, Kabupaten Manggarai terletak di $08^{\circ} .14^{\prime}$ LS - $09^{\circ} .00$ LS $/^{\circ}$ Lintang Selatan dan $120^{\circ} .20^{\prime}$ BT $-120^{\circ} .55^{\circ}$ Bujur Timur (Umiyati dan Kosmas, 2015:147). 
Kajian sintaksis membedah beberapa unsur penting, misalnya, fungsi, kategori, dan peran sintaksis (Chaer, 2009:20). Menurut Verhaar (1983:11), fungsi sintaksis adalah tempattempat struktur sintaksis yang berisi kategori-kategori tertentu. Beberapa kategori dimaksud, misalnya, subjek (S), predikat (P), objek (O), komplemen (Kom), dan keterangan (Ket). Dalam studi sintaksis, sebuah klausa terdiri atas argumen inti dan periferal. Secara fungsional, verba disebut predikat. Dalam praktiknya, sebuah verba selalu diikuti dengan nomina atau frasa nominal. Karena posisi demikian, sebuah verba sering disebut sebagai fungsi argumen inti atau induk (Susandhika, dkk, 2016:20-36). Menurut Susandhika, dkk., verba berperan sebagai pengungkap suatu keadaan, kejadian, atau kegiatan. Setiap keadaan, kejadian, dan kegiatan selalu melibatkan satu atau lebih orang atau benda. Orang dan benda adalah peserta dalam keadaan dan kejadian atau kegiatan yang diterangkan verba dalam posisinya sebagai predikat.

Peneliti tertarik untuk meneliti tentang fungsi sintaktis dan peran semantis bahasa Manggarai karena hingga saat ini belum ada satu pun peneliti yang meneliti tentang hal ini. Selain itu, terdapat beberapa hal unik dalam Bahasa Manggarai Dialek Manggarai Tengah (BMDMT) yang menarik untuk dikaji. Hal unik tersebut, di antaranya, adalah pertama, dalam konstruksi pasif BM memiliki pemarkah sintaksis le, l, li 'oleh'. Kedua, nama orang dan kata sapaan dalam BM selalu diawali dengan artikel hi. Contoh:

(1) Ise ongga anak koe hitu

3JMK pukul anak kecil itu

'Mereka memukul anak itu' (bentuk aktif)

(2) Anak koe hitu ongga l- ise

Anak kecil itu pukul oleh 3JM

'Anak kecil itu dipukul oleh mereka' (bentuk pasif)

(3) Hi Pondik mbele kaba

ART NAMA bunuh kerbau

'(Si) Pondik membunuh kerbau' (subjek nama)

Masalah dalam penelitian ini dapat dirumuskan sebagai berikut: Apa sajakah fungsi sintaktis argumen inti dalam bahasa Manggarai dialek Manggarai Tengah? Apa sajakah peran semantis yang diemban argumen inti dalam bahasa Manggarai dialek Manggarai Tengah?

\section{LANDASAN TEORI}

Bagian ini menjelaskan tentang dua teori yang dipakai dalam menganalisis fungsi sintaktis dan peran semantis BMDMT. Dua teori tersebut adalah teori tata bahasa leksikal-fungsional dan teori peran makro.

\subsection{Teori Tata Bahasa Leksikal-Fungsional}

Penelitian tentang fungsi sintaktis dan peran semantis BM Dialek Manggarai Tengah ini menggunakan teori Tata Bahasa Leksikal-Fungsional (untuk selanjutnya TFL). Teori ini dikemukakan oleh Bresnan dan Kaplan pada tahun 1970 dan mulai berkembang luas sejak tahun 1982. TLF tergolong tata bahasa generatif yang nontransformasional yang berbasiskan leksikon. Disebutkan bahwa TLF merujuk pada konsep dasar generatif. Artinya, tata bahasa terdiri atas seperangkat modul, prinsip-prinsip tertentu, dan kendala-kendala tertentu yang membentuk suatu mekanisme yang mampu menghasilkan ekspresi bahasa yang tidak terbatas jumlahnya. 
TLF menempatkan unsur leksikal sebagai dasar dalam penggabungan dan penghadiran unsur lain dalam membangun sebuah konstruksi. Dengan demikian, semua proses itu sangat bergantung pada aspek leksikal tersebut (Kaplan \& Bresnan, dalam Kosmas, 2015:119). Dengan demikian, unsur leksikal berperan penting dalam membangun sebuah konstruksi kebahasaan.

Selain berfokus pada aspek leksikal, hal penting lain yang dibahas dalam TLF adalah aspek fungsional. Dalam TLF, kata 'fungsional' lebih dipakai dalam artian 'fungsi matematis', yang tidak persis sama dengan penggunaan istilah 'fungsional' dalam wacana/penggunaan bahasa seperti halnya pada Tata Bahasa Sistemik Fungsional (Halliday, dalam Arka, 2003:108122; Kosmas, 2015:120). Dalam pengertian itu, fungsi dalam TLF dihubungkan dengan konsepsi relasi gramatikal (seperti SUBJ, OBJ, dsb.). Artinya, fungsi kebahasaan dapat dimodelkan dengan struktur matrik dengan relasi gramatikal dan informasi lainnya membentuk pasangan atribut dan nilai dalam struktur formal yang disebut struktur-fungsional (str-f).

\subsection{Teori Peran Makro (Macro Roles)}

Van Valin (2005:60) menyebutkan dua peran semantik, yakni pelaku (actor) dan pengalam (undergoer). Penentuan peran pelaku dalam setiap perilaku yang ditampilkan memiliki tingkat kesulitan yang tinggi dalam pemaknaan karena makna perilaku seorang pelaku bersifat intuitif. Karena sifatnya yang demikian, ada kemungkinan bahwa sebuah argumen inti memiliki beberapa peran semantis yang berbeda.

Disebutkan bahwa pelaku (actor) adalah argumen yang melakukan tindakan membentuk (perform), memengaruhi, menghasut (instigate), atau mengendalikan situasi yang dinyatakan oleh predikatnya. Di lain pihak, pengalam (undergoer) adalah argumen yang mengekspresikan partisipan yang tidak membentuk, tidak mengendalikan situasi, tetapi dipengaruhi oleh tindakan yang dinyatakan dalam verbanya.

Kedua peran ini bersifat tetap meskipun wujud sintaksisnya berbeda. Pelaku dan pengalam disebut sebagai argumen predikat transitif dan argumen predikat intransitif. Hal ini menunjukkan bahwa keduanya berbeda dengan relasi sintaksis seperti subjek dan objek ataupun peran kasus (case role) seperti agen dan pasien. Adapun realisasinya pada sebuah argumen verba akan memunculkan berbagai peran yang berbeda sesuai dengan ciri semantis predikatnya (Van Valin, 2005:60). Kedua peran yang dijelaskan di atas merupakan peran umum. Di dalam peran umum tersebut terdapat pula peran-peran khusus. Beberapa di antaranya adalah agen, pemengaruh, lokatif, tema, dan pasien. Karena pembagian peran yang demikian, Foley dan Van Valin (1994:59) membuat hierarki tematis untuk memudahkan penafsiran pelbagai peran semantis turunan serta menerangkan peran semantis yang mungkin dilibatkan dalam pemetaan (mapping) argumennya.

Van Valin dan Lapola (1999) mengajukan beberapa prinsip umum untuk menentukan peran makro, yaitu jumlah dan sifat. Jumlah peran makroverba kurang atau sama dengan jumlah argumen pada struktur logisnya. Jika suatu verba memiliki dua argumen atau lebih pada struktur logisnya, verba itu memiliki dua peran makro. Jika suatu verba memiliki satu argumen atau lebih pada struktur logisnya, verba itu memiliki satu peran makro.

\section{METODOLOGI PENELITIAN}

Penelitian ini menggunakan pendekatan kualitatif yang bertujuan untuk menggambarkan dan menjelaskan realita fungsi sintaktis dan peran semantis argumen inti BM dialek Manggarai 
Tengah. Data dianalisis melalui pemaparan realita secara natural dan apa adanya. Data didukung dengan pendekatan deduktif dan induktif, dan dikumpulkan pada kondisi yang alamiah dengan menggunakan metode penelitian linguistik lapangan dan metode kepustakaan (dokumenter). Penelitian linguistik lapangan yang melibatkan partisipasi narasumber bahasa secara langsung dilakukan dengan metode khusus, yaitu metode simak dan metode cakap. Metode simak merupakan metode yang dilakukan dengan penyimakan, sedangkan metode cakap berupa percakapan antara peneliti dan informan. Metode simak mencakup teknik sadap, teknik simak libat cakap, teknik simak bebas libat cakap, teknik rekam, dan teknik catat (Sudaryanto 1993).

Metode lain yang digunakan adalah metode kepustakaan (dokumenter). Metode ini digunakan untuk menunjang data lisan dengan mengumpulkan data dalam bentuk korpus teks kepustakaan. Metode ini diterapkan dengan cara mengambil sejumlah data berupa klausa/ kalimat BM dialek Manggarai Tengah dari sumber data berupa cerita rakyat.

Dalam penelitian ini, peneliti menggunakan data primer (teks lisan) dan data sekunder (teks tertulis). Data primer dalam penelitian ini adalah data yang diperoleh peneliti secara langsung dari penutur asli bahasa Manggarai dialek Manggarai Tengah yang kemudian direkam oleh peneliti. Data sekunder dalam penelitian ini adalah data yang diambil peneliti dari sumber yang sudah ada, yaitu teks cerita rakyat daerah Manggarai. Beberapa cerita rakyat Manggarai yang diambil sebagai data adalah Hi Bokes Agu Kode Ata Nganceng Dere (HBAKAND), Lolo Sai Loek Mata agu Lolo Riti (LSLMaLR), Nunduk Loke Nggerang (NLN), Pake Mese Ata Mese Nai (PMAMN), Tara Mangan Golo Mawe (TMGM), Tara Mangan Poco Weri Ata (TMPWA), dan hi Pondik (PON).

\section{PEMBAHASAN}

Pembahasan hasil penelitian didahului dengan penjelasan tentang struktur klausa BMDMT. Hal ini penting untuk dibahas karena fungsi sintaktis dan peran semantis hanya bisa dijelaskan jika ada pemahaman tentang struktur klausa. Setelah itu, pembahasan dilanjutkan dengan penjelasan tentang fungsi sintaktis dan peran semantis BMDMT.

\subsection{Klausa Bahasa Manggarai Dialek Manggarai Tengah}

Dalam bahasa Manggarai, ada dua jenis klausa: klausa verbal dan klausa nonverbal. Klausa verbal terdiri atas klausa monotransitif, klausa dwitransitif, dan klausa intransitif. Klausa nonverbal terdiri atas klausa nominal, klausa preposisional, klausa adjektival, dan klausa numeral.

\subsubsection{Klausa Verbal}

Chaer (2009:42) mendefinisikan klausa verbal sebagai klausa yang predikatnya berkategori verba. Verhaar (1996:164) menjelaskan bahwa di dalam klausa verbal, konstituen induk adalah verba, secara fungsional dinamakan 'predikat' verba dan selalu disertai oleh satu nomina dapat juga lebih dari satu nomina - atau frasa nominal. Nomina atau frasa nominal itu dibedakan menjadi dua jenis, yakni konstituen inti atau nuklir dan konstituen luar inti atau periferal. Konstituen inti adalah konstituen yang hadir karena sifat-sifat yang khas dari verba yang menjadi induk seluruh kontruksi. Sementara itu, konstituen luar inti atau periferal merupakan pewatas. Hanya konstituen inti saja yang dapat disebut peserta atau argumen. 


\subsubsection{Klausa Transitif}

Menurut Givón (2001:141) verba transitif ditandai dengan peserta wajib. Satu berperan sebagai subjek dan dua lainnya sebagai objek. Dari kedua objek tersebut, satu objek berfungsi sebagai objek langsung dan objek yang lain berfungsi sebagai objek tak langsung. Subjek dari sebuah verba dwitransitif secara khas berperan sebagai agen dan salah satu objeknya berperan sebagai pasien. Di bawah ini adalah contoh-contoh klausa transitif dalam BMDMT.

(4) Hia ngo deko ikang

3TGL pergi tangkap ikan

'Dia pergi menangkap ikan'

(5) Ngo kawe motang hi ema

pergi cari babihutan ART bapak

'Si bapak pergi mencari babi hutan'

(6) Aku teing tuang-m hi Bokes cempulu petak uma woja 1TGL beri tuan-KLIPOS ART NAMA NUM petak kebun padi 'Saya memberikan tuanmu Bokes sepuluh petak sawah'

Frasa yang berhuruf tebal pada contoh-contoh di atas merupakan verba transitif. Dalam klausa transitif BMDMT, pada umumnya terdapat dua verba atau yang biasa disebut dengan verba serial seperti pada (4) dan (5). Contoh (4) dan (5) merupakan klausa monotransitif dan data (6) merupakan klausa dwitransitif.

Berdasarkan data di atas, struktur klausa transitif BMDMT sangat beragam. Pada contoh (5), yang merupakan jenis klausa inversi/nonkanonis (argumennya terletak di belakang verba), klausa diawali dengan verba atau predikat serial, yakni ngo kawe 'pergi mencari', kemudian diikuti objek motang 'babi hutan' dan subjek hi ema 'si bapak'. Pada contoh (6), struktur klausanya berupa struktur kanonik (argumennya berada di depan verba) dengan urutan subjek hia 'dia', predikat yang berupa predikat serial ngo deko 'pergi tangkap', dan objek ikang 'ikan'. Contoh (6) yang juga merupakan klausa kanonis yang diawali dengan S hia 'dia' dan diikuti oleh $\mathrm{P}$ teing 'beri', $\mathrm{O}$ tuangm hi Bokes 'tuanmu si Bokes', dan $\mathrm{O}_{\theta}$ cempulu petak uma sawah 'sepuluh petak sawah'.

Berdasarkan penjelasan di atas, dapat disimpulkan bahwa, pertama, terdapat dua struktur klausa monotransitif dalam BMDMT, antara lain, $S+P+O$ ( struktur dasar)dan $P+O+S$. Kedua struktur monotransitif tersebut tidak mengalami perubahan pada maknanya. Kedua, pada klausa dwitransitif dalam BMDMT posisi verba atau predikat diletakkan setelah subjek. Klausa dwitransitif memiliki struktur $S+P+O+O_{\theta}$.

\subsubsection{Klausa Intransitif}

Data (7) - (13) merupakan klausa intransitif dalam BMDMT. Seperti halnya bahasa Indonesia, klausa intransitif dalam BMDMT tidak membutuhkan kehadiran objek. Singkatan yang tertera di belakang setiap contoh menunjukkan sumber teks cerita rakyat.

(7) Hia toko one uma - $n$

3TGL tidur PREP kebun-KLIPOS

'Dia tidur di kebunnya' 
(8) Hia ngo lau uma

(TMGM)

3TGL pergi PREP kebun

'Dia pergi ke kebun'

(9) Mburukngo sina mbaru gendang hia

(PMAMN)

lari pergi PREP rumah besar 3TGL

'Dia berlari pergi ke rumah gendang'

(10) Pake anakngo pe'ang mai liang

(PMAMN)

Katak anak pergi luar datang gua

'Anak katak pergi ke luar lubang'

(11) Hia ngo one sawa

3TGL pergi PREP sawah

'Dia pergi ke sawah'

(12) Woncek-woncek hia one sawa

Lompat-lompat 3TGL PREP sawah

'Dia melompat- lompat di sawah'

(13) Tikul pake anakho'o bolo mai rangade ende- $n$ (PMAMN)

Berlutut katak anak ini depan datang muka POS ibu- KLIPOS

'Anak katak berlutut dihadapan ibunya'

Kata yang berhuruf tebal pada contoh-contoh di atas merupakan verba intransitif. Verba intransitif pada klausa di atas adalah toko 'tidur', ngo 'pergi', woncek- woncek 'lompat-lompat', mburuk ngo 'berlari pergi', dan tikul 'berlutut'. Contoh-contoh di atas juga menunjukkan bahwa terdapat tiga struktur klausa intransitif dalam BMDMT. Pertama, S + P + Ket seperti pada (7), (8), (10), dan (11), dengan hia 'dia' (7), (8), dan (11) dan pake anak 'katak anak' (10) sebagai subjek; toko 'tidur' (7) dan ngo 'pergi' (8), (10), dan (11) sebagai predikat; sedangkan one sawa 'di sawah' (11), lau uma 'di kebun' (7), peang mai liang 'di luar gua' (10) sebagai keterangan. Dalam kalimat intransitif kehadiran keterangan bersifat opsional, bisa ada dan bisa juga tidak.

Kedua, $\mathrm{P}+\mathrm{Ket}+\mathrm{S}$ seperti pada (9), dengan mburuk ngo 'berlari pergi' sebagai verba/predikat serial, sina mbaru gendang 'di rumah gendang'sebagai keterangan, dan hia 'dia' sebagai subjek.

Ketiga, P + S + Ket seperti pada (12) dan (13), dengan woncek-woncek 'lompatlompat'pada (12) dan tikul 'berlutut'pada (13) sebagai verba/predikat; hia 'dia' pada (12) dan pake anak 'katak anak' pada (13) sebagai subjek; dan one sawa 'di sawah'pada (12) dan bolo mai ranga de enden 'di depan muka ibunya' (13) menempati fungsi keterangan.

Selain itu, semua bentuk pasif dalam BMDMT merupakan klausa intransitif karena bentuk pasif tidak memiliki objek. Satu-satunya argumen inti dalam bentuk pasif adalah subjek.

(14) a. Ngo cumang le hau hi kraeng Nggulak
pergi bertemu oleh 2TGL ART tuan NAMA
'Si Tuan Nggulak kau temui'
b. Hia dolong le kode
3TGL kejar oleh kera
'Dia dikejar oleh kera'
c. Dolong hia le kode
kejar 3TGL oleh kera
'Dia dikejar oleh kera'


Pada (14a), posisi verba berada di depan oblik dan posisi subjek berada pada akhir klausa. Subjek pada klausa di atas adalah hi kraeng Nggulak 'si tuan Nggulak' yang merupakan satu-satunya argumen inti. Ngo cumang 'pergi bertemu' merupakan verba atau predikat. Le hau 'oleh kau' merupakan oblik penerima yang dimarkahi oleh preposisi le yang berfungsi sebagai bentuk pasif. Pada contoh (14b), subjek hia 'dia' yang merupakan satu-satunya argumen inti berada di awal klausa, lalu diikuti verba/predikat dan diakhiri oleh oblik. Contoh (14c) menunjukkan bahwa dalam bentuk pasif, subjek hia 'dia' berada langsung setelah predikat dolong 'kejar'. Struktur klausa intransitif bentuk pasif berdasarkan data di atas adalah $\mathrm{P}+\mathrm{OBL}$ $+\mathrm{S}, \mathrm{S}+\mathrm{P}+\mathrm{OBL}$, dan $\mathrm{P}+\mathrm{S}+\mathrm{OB}$.

\subsubsection{Klausa Nonverbal}

Jika dilihat dari jumlah argumen, jumlah argumen klausa nonverbal sama dengan klausa intransitif. Hal ini disebabkan karena baik klausa nonverbal maupun klausa intransitif hanya mengikat satu argumen inti yaitu subjek (SUBJ). Berdasarkan kategori kata atau frasa yang menduduki fungsi predikat, klausa nonverbal dibagi menjadi empat, yaitu klausa nominal, klausa preposisional, klausa adjektival, dan klausa numeral.

\subsubsection{Klausa Nominal}

Klausa pada contoh (15) - (17) merupakan klausa nominal karena didukung oleh beberapa bukti nominal. Pertama, eman 'bapaknya', enden' ibunya', inewai molas hitu 'gadis cantik itu' merupakan nomina yang mengisi fungsi S. Kedua, kata ho'o 'ini' atau hitu 'itu' menjadi penanda sebuah subjek. Ketiga, nomina yang mengisi fungsi $S$ dapat dideskripsikan dengan nama pada nomina pengisi fungsi $\mathrm{P}$, seperti pada data (17). Contoh-contoh di bawah ini menunjukkan bahwa klausa nominal dalam BMDMT memiliki struktur $\mathrm{S}+\mathrm{P}$ seperti pada (15) dan (17) dan P + S seperti pada (16).

(15) Ema - $n$ hi Nggerang hoo manusia - $i$

Bapak-KLIPOS ART NAMA ini manusia -PC

'Bapak Nggerang ini manusia'

(16) Darat ende- $n$

$(\mathrm{NLN})$

Setan ibu- KLIPOS

'Ibunya setan'

(17) Inewai molas hitu hi Nggerang

perempuan cantik itu ART NAMA

'Gadis itu si Nggerang'

\subsubsection{Klausa Preposisional}

Pada contoh (18) dan (22), posisi S berada pada akhir klausa. Subjek tersebut adalah hi Bokes 'si Bokes' dan kula 'musang'. Pada (19) - (21), posisi S tetap berada pada awal klausa yakni di depan predikat yang berupa preposisi. Dengan demikian, struktur klausa preposisional dalam BMDMT dapat diklasifikasikan ke dalam dua bentuk, yaitu $\mathrm{S}+\mathrm{P}$ dan $\mathrm{P}+\mathrm{S}$.

(18) Lau mbaru hi Bokes

(HBAKAND)

PREP rumah ART NAMA

'Si Bokes di rumah' 
(19) Lawa one beo hitu

Rakyat PREP kampung itu

'Penduduk di kampung itu'

(20) Pake ine mese one liang

(PMAMN)

Katak induk besar PREP lubang

'Induk katak besar di lubang'

(21) Tete so'o one mai dara agu toko d- aku (TMPWA

Ubi ini PREP darah KONJ tulang POS- 1TGL

'Ubi ini dari darah dan tulangku'

(22) Eta lobo haju kula ho'o

PREP kayu musang ini

'Musang di atas kayu'

\subsubsection{Klausa Adjektival}

Pada data (23) - (25) frasa rabo mese 'marah besar', molas ketai 'cantik sekali', dan bowok taung 'hancur semua' merupakan predikat yang berkategori sebagai adjektiva atau kata sifat. Posisi subjek hi Raja Bima hitu 'si Raja Bima itu' pada (23) dan hajun 'kayunya' pada (25) berada pada akhir klausa atau setelah predikat. Struktur klausa (23) - (25) dapat diubah posisi katanya tanpa mengubah maknanya.

(23) Rabo mese hi Raja Bima hitu

$(\mathrm{NLN})$

marah besar ART raja Bima itu

'Murkalah si Raja Bima itu'

(24) Hia hoo molas keta - $i$

3TGL ini cantik sangat-PC

'Dia sangat cantik'

(25) Bowok taung haju-n ga

$(\mathrm{NLN})$

Lapuk semua kayu -KLI POSPART

'Lapuk kayunya'

Berdasarkan data (23-25) di atas, dapat disimpulkan bahwa BMDMT memiliki dua struktur klausa adjektival. Pertama, $\mathrm{S}+\mathrm{P}$ (struktur dasar) seperti pada (24). Kedua, $\mathrm{P}+\mathrm{S}$, seperti pada (23 dan 25), yaitu posisi $\mathrm{P}$ berada di awal klausa, sedangkan $\mathrm{S}$ berada setelahnya.

\subsubsection{Klausa Numeralia}

Contoh (26) - (28) merupakan klausa numeralia dalam BMDMT. Pada contoh (26) dan (27), posisi P yang merupakan frasa numeralia berada pada awal klausa, yakni di depan S. Jadi, dapat dikatakan bahwa struktur klausa numeralia pada data (26) dan (27) adalah P + S. Pada data (28), posisi S tetap berada di depan P, yakni anak daku 'anak saya' merupakan S dan ca mongko 'satu biji' merupakan P yang berupa frasa numeralia. Seperti yang dijelaskan di atas bahwa dalam bahasa Indonesia ragam formal, fungsi $\mathrm{P}$ akan diisi oleh verba. Akan tetapi, dalam BMDMT fungsi $\mathrm{P}$ tetap diisi oleh frasa numeralia karena BMDMT tidak memiliki ragam baku atau tidak baku, seperti dalam bahasa Indonesia.

(26) Telu taus anak - $n$

(TMPWA)

NUM orang anak - KLIPOS

'Tiga orang anaknya' 
(27)
$\mathrm{Ca}$ anak ata rona
d- ise
NUM anak laki-laki
POS 3JMK

'Satu anak laki- laki mereka'

(28) Anak d- aku ce- mongko anak POS 1TGL NUM biji

'Anak saya satu orang'
(TMPWA)

(TMPWA)

\subsection{Fungsi Sintaksis Bahasa Manggarai Dialek Manggarai Tengah}

Bagian ini membahas beberapa fungsi sintaktis BMDMT. Pembahasannya dimulai dari penjelasan tentang subjek, objek, dan objek teta.

\subsubsection{Subjek}

Hasil penelitian ini menemukan lima indikator pengetesan subjek dalam BMDMT antara lain, (1) posisi kanonikal, (2) kontrol, (3) penaikan, (4) pejangka kambang, dan (5) penyisipan adverbial. Kelima strategi pengetesan subjek tersebut akan dijelaskan sebagai berikut.

\subsubsection{Posisi Kanonikal}

Yang dimaksud dengan posisi kanonikal adalah fungsi Subjek berada pada posisi praverbal atau pada posisi kiri predikat. Data (29) - (30) merupakan klausa monotransitif yang bervalensi dua atau mengikat dua argumen inti.Namun, data (31) merupakan klausa dwitransitif yang bervalensi tiga atau mengikat tiga argumen inti. Hia 'dia' pada (29), ise 'mereka' pada (30), dan $a k u$ 'saya' pada (31) merupakan argumen inti yang berfungsi sebagai subjek (S) dan berkategori nomina (N). Frasa ngo deko 'pergi tangkap', mbele 'bunuh', dan teing 'beri' pada klausa-klausa di atas adalah predikat/verba yang merupakan inti atau nukleus.
(29) Hia ngo deko ikang
3TGL pergi tangkap ikan
(HBAKAND)
'Dia pergi menangkap ikan'
(30) Ise mbele hi Nggerang (NLN)
3JMK bunuh ART NAMA
'Mereka membunuh si Nggerang'
(31) Aku teing hi Bokes cempulu petak uma woja
1TGL beri ART NAMA NUM petak kebun padi
'Saya memberikan si Bokes sepuluh petak sawah'
(HBAKAND)

Sama seperti pada klausa transitif (monotransitif dan dwitransitif) di atas, SUBJ yang muncul pada posisi kiri predikat juga terdapat dalam klausa intransitif, seperti pada (32) dan (33) berikut.

(32) Hia toko one uma $n$

(TMGM)

3TGL tidur PREP kebun- KLI

'Dia tidur di kebunnya'
(33) Hia ngo lau uma
3TGL pergi PREP kebun
'Dia pergi ke kebun'


Dalam struktur kanonis, klausa (32) dan (33) di atas merupakan klausa intransitif yang mengikat hanya satu argumen atau bervalensi satu. Hia 'dia' (32) dan (33) merupakan argumen inti yang secara sintaksis berfungsi sebagai subjek (SUBJ) dan berkategori nomina (N). SUBJ pada klausa (32) dan (33) di atas muncul pada posisi praverbal atau pada posisi kiri verba sebagai konstituen inti klausa, yakni toko 'tidur' pada (32) dan ngo 'pergi' pada (33).

\subsubsection{Kontrol}

Kroeger (2004) menjelaskan pembagian klausa menjadi dua jenis yakni klausa bebas dan klausa terikat. Data pada (34) berkategori klausa bebas. Dengan demikian, semua unsur klausa dapat dikontrol. Pada data (34a), subjek dari verba losi 'lari' bisa dilesapkan.Di sini, yang lari adalah hi Bokes 'si Bokes'. Pada data (34c), subjek verba losi 'lari' diekspresikan secara eksplisit yang ini dipahami yang lari adalah Pondik, bukan hi Bokes.

(34) a. Hi Bokes ongga hi Pondik poli hitu losi

ART NAMA pukul ART NAMA setelah itu lari

'Si Bokes memukul Si Pondik lalu lari'

b. Hi Bokes onggahi Pondik poli hitu [*losi ART NAMA pukul ART NAMA setelah itu lari 'Si Bokes memukul Si Pondik lalu lari'

c. Hi Bokes onggahi Pondik poli hitu [*hia losi ART NAMA pukul ART NAMA setelah itu 3TGL lari 'Si Bokes memukul Si Pondik lalu lari'

\subsubsection{Penaikan}

Menurut Kroeger (2004), dalam klausa bebas, unsur klausa dapat dipindahkan. Klausa pada contoh (35a) merupakan jenis klausa transitif atau klausa bebas karena berpredikat transitif. Data (35b) merupakan data yang sudah mengalami penaikan fungsi gramatikal. $A k u$ 'saya' pada (35a) merupakan OBJ yang mengalami penaikan menjadi SUBJ pada data (35b).

(35) a. Hia ongga aku

3TGL pukul 1TGL

'Dia memukul saya'

b. Aku ongga l- iha

1TGL pukul oleh 3TGL

'saya dipukul oleh dia'

\subsubsection{Pejangka Kambang}

Perilaku pejangka kambang pada (36) di atas merupakan contoh yang mewakili semua jenis klausa dalam BMDMT. Seperti yang dijelaskan sebelumnya bahwa pejangka kambang bisa menduduki lebih dari satu posisi tanpa mengubah makna kalimat/klausa tersebut seperti pada data (36) di atas. Data tersebut menunjukkan bahwa dalam BMDMT, hanya subjek yang memiliki argumen inti. Oleh karena itu, penjelasannya merujuk pada subjek dan bukan objek.
(36) $\mathrm{a}$

$$
\text { PJ }
$$

'Semua mereka pergi kerja'

(ELI) 
b. Ise sanggen taung ngo duat

3JMK PJ pergi kerja

'Mereka semua pergi kerja'

c. Ngo duat ise sanggen taung

pergi kerja 3JMK PJ

'Pergi kerja mereka semua'

d. Ise ngo duat sanggen taung

3JMK pergi kerja PJ

'Mereka pergi kerja semua'

\subsubsection{Penyisipan Adverbial}

Klausa (37a) merupakan sebuah predikat intransitif yang mengikat hanya satu argumen inti, yaitu Hi Pondik 'Si Pondik'. Secara sintaksis frasa di atas berfungsi sebagai SUBJ dan bisa disisipi adverbial kemungkinan seperti pada (37b), tetapi akan menjadi tidak berterima ketika adverbial yang sama disisipi di antara verba dan keterangan, seperti pada (37c).

(37) a. Hi Pondik ngo lau uma

ART NAMA pergi PREP kebun

'Si Pondik pergi ke kebun'

b. Hi Pondik am ngo lau uma

ART NAMA mungkin pergi PREP kebun

'Si Pondik mungkin pergi ke kebun'

c. *Hi Pondik ngo am lau uma

ART NAMA pergi mungkin ke kebun

'Si Pondik mungkin pergi ke kebun'

Selain pada klausa intransitif, penyisipan adverbial juga bisa dilakukan pada klausa transitif, yakni monotransitif dan dwitransitif seperti pada data (38) - (40) berikut.

(38) a. Hia ita kaka mese

(PMAMN)

3TGL lihat ular besar

'Dia melihat ular besar'

b. Hia bao ita kaka mese

(PMAMN)

3TGL tadi lihat ular besar

'Dia tadi melihat ular besar'

(39) a. Hia tuke haju hoo

(LSLMaLR)

2TGL panjat kayu ini

'Dia memanjat pohon'

c. Hia nanang keta tuke haju hoo

(LSLMaLR)

2TGL suka sangat panjat kayu ini

'Dia sangat suka memanjat pohon'

(40) a. Aku teing hi Bokes uma duat

(HBAKAND)

1TGL beri ART NAMA kebun

'Saya memberi si Bokes kebun'

d. Aku suan ntaung olo teing hi Bokes uma duat (HBAKAND)

1TGL dua tahun lalu beri ART NAMA kebun

'Saya dua tahun lalu memberi si Bokes kebun' 
Data (38) - (40) di atas merupakan klausa transitif yakni data (38) dan (39) adalah klausa monotransitif dan data (40) adalah klausa dwitransitif. Data (38a) merupakan data asli sedangkan data (38b) merupakan data yang telah disisipi adverbial waktu bao 'tadi' di antara SUBJ dan PRED. Demikian juga pada data (39a) merupakan data asli, sedangkan data (39b) merupakan data yang telah disisipi adverbial intensitas nanang keta 'sangat suka' di antara SUBJ dan PRED. Dengan demikian, dapat disimpulkan bahwa pengetesan subjek dalam BMDMT dengan cara penyisipan adverbial hanya dapat dilakukan pada adverbial waktu dan intensitas saja.

\subsubsection{Objek (OBJ)}

Salah satu bagian penting dalam sebuah kalimat adalah objek. Objek adalah bagian dari verba yang menjadi predikat dalam klausa itu. Kehadiran objek sangat ditentukan oleh ketransitifan verba itu (Chaer 2008:22). Seperti yang kita ketahui, objek dapat dibagi menjadi dua bagian, yakni objek langsung (direct object) dan objek tak langsung (indirect object). Menurut Van Valin (2004:35), objek langsung biasanya muncul pada bentuk akusatif. Data (41) dan (42) di bawah ini merupakan contoh objek dalam BMDMT.

$\begin{array}{lll}\text { (41) } H i \quad \text { Pondik weli sa'i kaba hitu } & \text { (PON) } \\ \text { ART NAMA beli kepala kerbau itu } & \\ \text { 'Si Pondik membeli kepala kerbau itu' } & \\ \text { (42) Hia tuke haju } & \text { (LSLMaLR) } \\ \text { 2TGL panjat kayu } & \\ \text { 'Dia memanjat pohon' } & \end{array}$

Klausa (41) dan (42) merupakan klausa monotransitif. Klausa monotransitif adalah klausa yang mengikat satu argumen inti selain subjek. Klausa hi pondik weli sa'i kaba hitu 'si Pondik membeli kepala kerbau itu' (41) memiliki dua argumen inti, yaitu subjek dan objek. Frasa sa'i kaba hitu 'kepala kerbau itu' secara sintaksis berfungsi sebagai objek. Weli 'beli' merupakan inti atau nukleus yang secara sintaksis berfungsi sebagai predikat/verba. Klausa hia tuke haju 'dia memanjat pohon' (42) juga memiliki dua argumen inti, yakni hia 'dia' sebagai subjek dan haju 'kayu' sebagai objek. Tuke 'panjat' merupakan inti atau nukleus yang juga secara sintaksis berfungsi sebagai predikat.

\subsubsection{Objek Teta $\left(\mathrm{OBJ}_{\theta}\right)$}

Objek dibagi menjadi objek (OBJ) dan objek teta (OBJ $\theta$ ) (Bresnan 2016:94-97). Menurut Van Vallin (2004:35), objek tak langsung muncul pada bentuk datif.

(43) Aku teing tuang-m hi Bokes cempulu petak uma woja

(HBAKAND)

1TGL beri tuan-KLI ART NAMA NUM petak kebun padi

'Saya memberikan tuanmu Bokes sepuluh petak sawah'

(44) Aku teing hau umawoja, ute, agu latung

(TMPWA)

1TGL beri 2TGL sawah, sayur KONJ jagung

'Saya memberi kau sawah, kebun sayur, dan kebun jagung'

Klausa pada data (43) dan (44) merupakan klausa dwitransitif atau bitransitif karena mengikat dua argumen inti selain subjek. Klausa aku teing tuangm hi Bokes cempulu petak uma 'saya memberikan tuanmu Bokes sepuluh petak sawah' (43) terdiri atas satu nukleus dan tiga 
argumen inti. Teing 'beri' merupakan inti atau nukleus dari klausa tersebut yang berfungsi sebagai predikat dan berkategori verba. $A k u$ 'saya' berfungsi sebagai subjek dan berkategori nomina, tuangm hi Bokes 'tuanmu si Bokes' berfungsi sebagai objek utama atau OBJ dan berkategori nomina, sedangkan cempulu petak uma 'sepuluh petak sawah' berfungsi sebagai objek sekunder atau $\mathrm{OBJ}_{\theta}$ yang berkategori nomina. Pada klausa (44), aku 'saya' secara sintaksis merupakan subjek yang berkategori nomina, teing 'beri' merupakan predikat/verba, hau 'kau' merupakan atau OBJ dan uma woja, ute agu latung 'sawah, kebun sayur, dan kebun jagung' merupakan $\mathrm{OBJ}_{\theta}$.

Berdasarkan analisis data (29) - (44) ditemukan beberapa fungsi sintaksis argumen inti dalam BMDMT. Fungsi tersebut adalah subjek (SUBJ), objek (OBJ), dan Objek Teta $\left(\mathrm{OBJ}_{\theta}\right)$.

\subsection{Peran Semantis Argumen Inti Bahasa Manggarai Dialek Manggarai Tengah}

Van Valin Jr. (2005:60) menyebutkan bahwa terdapat dua peran semantik, yakni pelaku (actor) dan pengalam (undergoer). Pelaku adalah argumen yang melakukan tindakan membentuk (performs), memengaruhi (effects), menghasut (instigates), atau mengendalikan situasi yang dinyatakan oleh predikatnya. Sementara itu, pengalam adalah argumen yang mengekspresikan partisipan yang tidak membentuk, tidak mengendalikan situasi, tetapi dipengaruhi oleh tindakan yang dinyatakan dalam predikat. Berikut adalah beberapa peran semantik dalam BMDMT.

\subsubsection{Pelaku (Agent)}

Agen merupakan peran yang diisi oleh frasa nomina atau kata benda (Van Valin 2005:23). Dalam bentuk aktif, agen adalah subjek dan pasien adalah objek langsung, sedangkan dalam bentuk pasif, pasien adalah subjek dan agen bukan merupakan subjek. Agen merupakan pelaku yang melakukan tindakan atau aksi sesuai dengan yang diinginkannya. Dengan kata lain, agen adalah instigator yang melakukan tindakan atau peristiwa dengan sengaja dan dengan tujuan tertentu (Iswara 2015:388).

$\begin{array}{lll}\text { (45) Hia ngo deko ikang } & \text { (HBAKAND) } \\ \text { 3TGL pergi tangkap ikan } & \\ \text { 'Dia pergi menangkap ikan' } & \text { (NLN) } \\ \text { (46) Ise mbele hi Nggerang } & \\ \text { 3JMK bunuh ART NAMA } & \end{array}$

Data (45) dan (46) di atas menunjukkan adanya peran tertentu dalam setiap unsur kalimat dalam BMDMT. Argumen hia 'dia' (45) dan ise 'mereka' (46) berperan sebagai pelaku karena merupakan pelaku dari predikat ngo deko 'pergi tangkap'(45) dan mbele 'bunuh' (46).

\subsubsection{Penyebab (Effector)}

Argumen yang berfungsi sebagai penyebab (efektor) umumnya merupakan pelaku tindakan atau peristiwa yang dilakukan, baik sengaja maupun tidak sengaja (Iswara 2015: 389). Menurut Trask (1996:88), efektor adalah frasa nomina yang memiliki prinsip seperti sebuah aktor.

(47) Usang warat pande tepo haju hitu

Hujan badai buat patah pohon itu

'Hujan badai mematahkan pohon itu' 
Data pada klausa (47) merupakan data yang di dalamnya terdapat peran argumen penyebab. Pande pa'u 'menjatuhkan/menumbangkan' merupakan predikat pada klausa di atas dan yang berperan sebagai efektor atau penyebab adalah usang warat 'hujan badai'. Disebut berperan sebagai efektor karena aktor melakukan tindakan tertentu yang berdampak pada objeknya.

\subsubsection{Pengalam (Experiencer)}

Pengalam adalah argumen yang menyatakan suatu yang mengalami dan kena suatu peristiwa psikologis, baik sensasi, emosi maupun kognitif (Parera 1993:125). Van Vallin dan Folley (1984:29) menjelaskan bahwa pengalam adalah suatu peran argumen yang tidak melakukan, menyelenggarakan, memainkan, memulai, memprakarsai atau mengontrol keadaan. Sementara itu, Trask (1996:97) mendefinisikan peran pengalam sebagai sebuah peran semantis yang berasal dari sebuah frasa nominal yang menyatakan sebuah benda yang bernyawa yang merasakan atau mengalami sesuatu. Data (48) berikut menjelaskan peran pengalam dalam BMDMT.

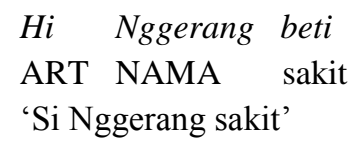

Pada data (48) di atas, argumen hi Nggerang 'si Nggerang' yang berperan sebagai pengalam merupakan sebuah frasa nominal bernyawa yang merasakan atau mengalami sesuatu.

\subsubsection{Penerima (Recipient)}

Van Vallin (2005:24) menjelaskan bahwa secara sintaksis penerima (recipient) dapat dilihat sebagai objek tak langsung seperti dalam Chris gave the notebook to Dana dan sebagai subjek pada klausa Sandy received the message from Bill. Pada klausa Chris gave the notebook to Dana, yang menjadi penerima adalah yang merupakan objek tak langsung. Sementara itu, pada klausa Sandy received the message from Bill, yang menjadi penerima adalah Sandy dan berfungsi sebagai subjek. Seperti halnya dalam bahasa Inggris, dalam BMDMT juga terdapat klausa yang menunjukkan recipient.

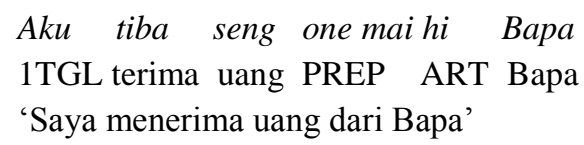

Data (49) di atas merupakan sebuah klausa yang di dalamnya terdapat peran penerima. $A k u$ 'saya' dalam klausa berperan sebagai penerima.

\subsubsection{Sumber (Source)}

Menurut Trask (1995:255), sumber adalah peran semantik yang dinyatakan oleh frasa nomina yang mengekpresikan titik awal gerak secara abstrak atau konkret. Iswara (2010) menjelaskan bahwa jika terdapat perpindahan, posisi awal merupakan sumber/ asal, objek merupakan tema dan posisi akhir merupakan penerima (receiver). Misalnya dalam kalimat 'Ayah memberikan sebuah permen kepada Vares'. Peran argumen Ayah dapat sebagai agen sekaligus sebagai 
sumber. Dalam kalimat 'Ibu membeli seekor ayam dari paman', peran ibu dapat sebagai agen sekaligus penerima atau receiver.

(50) Aku teing tuang-m hi Bokes cempulu petak uma woja

(HBAKAND)

1TGL beri tuan-KLI ART NAMA sepuluh petak sawah

'Saya memberi tuanmu Bokes sepuluh petak sawah'

Data (50) di atas merupakan klausa dwitransitif. $A k u$ 'saya' pada klausa di atas secara semantis berperan sebagai pelaku sekaligus sumber. Frasa cempulu petak uma woja 'sepuluh petak sawah' merupakan NP yang mengalami perpindahan posisi, sedangkan hi Bokes 'si Bokes' merupakan sasaran atau penerima.

\subsubsection{Tema (Theme)}

Tema merupakan peran sebuah argumen yang diletakan di suatu tempat atau sebuah argumen yang mengalami suatu perpindahan lokasi. Selain itu, peran tema juga menunjukkan entitas yang dimiliki atau yang mengalami perubahan kepemilikan (Van Vallin 2005:24). Peran tema memiliki kesamaan dengan peran pasien karena dikenai aktifitas atau aksi dari verba yang dilakukan oleh agen. Yang membedakannya adalah peran tema mengalami perpindahan atau pergerakan yang diakibatkan oleh verbanya (Iswara 2015:388). Perhatikan data berikut.

(51) Ata tua ema hitu weli wani one mai hi Pondik

(HP)

Bapak tua itu beli lebah PREP ART NAMA

'Bapak tua itu membeli lebah dari si Pondik'

Verba weli pada klausa di atas memiliki dua argumen inti, yakni ata tua ema hitu 'bapak tua itu' dan wani 'lebah'.Wani 'lebah' berperan sebagai tema. Peran tema wani 'lebah' pada data di atas mengalami perpindahan atau pergerakan yang diakibatkan oleh verbanya, yaitu verba weli 'beli'. Menurut Van Valin (2005:24), sebuah peran dikatakan berperan sebagai tema jika memiliki verba menyimpan, meletakkan, memberi, mengirim, dan membeli.

\subsubsection{Pasien (Patient)}

Pasien adalah sebuah argumen yang bernyawa maupun tidak bernyawa yang berada dalam suatu keadaan atau mengalami perubahan keadaan yang diakibatkan oleh verba. Pasien biasanya ditandai dengan munculnya verba membunuh, memukul, memecahkan, meremukan, mencuci, dan merusakan (Van Vallin 2005:24). Perhatikan data berikut.

Ise mbele hi Nggerang
3JMK bunuh ART NAMA

$(\mathrm{NLN})$

'Mereka membunuh si Nggerang'

Pada data (52) di atas, unsur hi Nggerang 'si Nggerang' merupakan sebuah argumen yang berperan sebagai pasien dan diikat oleh verba mbele 'bunuh'. Berdasarkan penjabaran di atas, dapat disimpulkan bahwa peran semantis BMDMT adalah pelaku, penyebab, pengalam, sumber, tema, dan pasien.

\section{SIMPULAN}

Berdasarkan analisis dapat disimpulkan bahwa pertama, fungsi sintaksis argumen inti BMDMT adalah SUBJ, OBJ danOBJ ${ }_{\ominus}$. Kedua, peran semantis argumen inti BMDMT dibagi ke dalam dua 
bagian, yakni peran makro dan peran tematis. Peran makro terdiri atas Actor dan Undergoer, sedangkan peran tematis terdiri atas agent (agen), effector (pemengaruh), experience (pengalam), goal/recepient (penerima), source (sumber), theme (tema),dan patient (pasien).

\section{CATATAN}

${ }^{1}$ Sebagian dari hasil penelitian tesis penulis untuk mendapatkan Master Humaniora, Prodi Linguistik Pascasarjana Undana yang dibimbing oleh Dr. Jeladu Kosmas, M.Hum. dan Drs. Yosep B. Kroon, Ph.D.

${ }^{2}$ Penulis berterima kasih kepada Bapak Jeladu Kosmas, Bapak Yosef B. Kroon, Bapak Simon Sabon Ola, dan Bapak Agustinus Semiun karena telah membimbing dan memberikan masukan konstruktif pada saat penyusunan tesis dan artikel ini.

\section{DAFTAR PUSTAKA}

Alwi, H. dkk. (1993). Tata Bahasa Baku Bahasa Indonesia. Jakarta: Perum Balai Pustaka.

Arifin, E. Z. dan H.M. Junaiyah. (2008). Sintaksis. Jakarta: PT Grasindo.

Arka, I W. (Tanpa Tahun). Bahasa-bahasa Nusantara: Tipologinya dan tantangannya bagi Tatabahasa Leksikal-Fungsional. https://www.researchgate.net/publication/265217604_ Bahasa-bahasa_Nusantara_Tipologinya_dan_tantangannya_bagi_Tatabahasa_LeksikalFungsional.

. (2003b). Tata bahasa leksikal-fungsional (Lexical-Functional Grammar): Prinsipprinsip utama dan tantangannya bagi analisis bahasa Nusantara. Dalam Kaswanti Purwo, B. (Peny.). PELBBA 16: 51 - 105. Jakarta: Pusat Kajian Bahasa dan Budaya, Unika Atma Jaya.

Badudu, J.S. (2005). Jangan lupa subjek dan predikat. http://pelitaku.sabda.org/jangan_ lupa_subjek_dan_predikat.

Blust, R. (1981). Linguistic evidence for some early Austronesian taboos. USA:Wiley.

Bresnan, J. (2016). Lexical-functional syntax. Second Edition. Oxford, UK: Blackwell Publishers Ltd.

Bungin, B. (2003). Analisis data penelitian kualitatif. Jakarta: PT Raja Grafindo Persada.

Chaer, A. (2009). Sintaksis bahasa Indonesia: Pendekatan proses. Jakarta: Rineka Cipta.

Chafe, W.L. (1970). Meaning and the structure of language. Chicago: The Chicago University Press.

Comrie, B. (1989). Language universals and linguistic typology, syntax and morphology. Second Edition. Chicago: The University of Chicago Press

Dixon, R.M.W. (2010). Basic linguistics theory, Volume 1: Methodology. Oxford: Oxford University Press.

Givón, T. (2001). Syntax: An introduction. Amsterdam/Philadelphia: John Benjamins Publishing Company.

Iswari, A. A. (2015). Fungsi sintaksis dan peran semantik argumen frasa verba bahasa Bali. Retorika, Jurnal Ilmu Bahasa, Vol. 1(2), Oktober 2015, 388-402. 
Kosmas, J. (2000). Pemetaan argumen aktor dalam bahasa Manggarai. Dalam Linguistika Tahun VI, Edisi keduabelas, 1-15. Denpasar: Program Magister (S2) Linguistik, Universitas Udayana.

. (2000). Argumen aktor dalam bahasa Manggarai dan pemetaan fungsinya" .Tesis. Denpasar: Program Pascasarjana Universitas Udayana.

. (2008). Klausa bahasa Rongga. Sebuah analisis leksikal fungsional. Disertasi. Denpasar: Program Pascasarjana Universitas Udayana.

. (2008). Frasa preposisional dan struktur adjung dalam bahasa Rongga. LOGAT.

. (2008). Perilaku penjangka kambang dalam bahasa Rongga. e-Journal of Linguistics.

. (2010). Konstruksi verba serial bahasa Rongga. Linguistika. Vol.17, No. 33.

. (2015). Konstruksi pasif bahasa Manggarai: Sebuah analisis leksikal fungsional. RETORIKA: Jurnal Ilmu Bahasa, Vol. 1(1), April 2015, 108-122.

Kridalaksana, H. (1986). Kelas kata dalam bahasa Indonesia. Jakarta: Gramedia.

Kurniawati, D.H. (2014). Perilaku sintaksis verba deadjektiva dalam bahasa Indonesia. Skripsi. Program Studi Bahasa Dan Sastra Indonesia, Fakultas Bahasa dan Seni, Universitas Negeri Yogyakarta.

Kroeger, P. (2004). Analyzing syntax: A lexical-functional approach. Cambridge: Cambridge University Press.

Nisrina, R.A. (2011). Struktur frasa pengisi fungsi predikat pada kumpulan romansa Jawa Tembange Wong Kangen, Skripsi. Jurusan Pendidikan Bahasa dan Sastra Jawa, Fakultas Bahasa dan Seni, Universitas Negeri Semarang.

Pateda, M. (1988). Linguistik: Sebuah pengantar. Bandung: Angkasa.

Radford, A. (2004). English syntax: An introduction. Cambridge: Cambridge University Press.

Semiun, A. \& Kosmas, J. (2016). Verb nominalization of Manggarai language: The case of Central Manggarai dialect in West Flores Indonesia. International Journal of Language and Literature. June 2016, Vol. 4(1), pp. 122-136.

Sudaryanto. (1993). Metode dan aneka teknik analisis bahasa. Jakarta: Duta Wacana.

Sukerti, G.N.A. (2013). Relasi gramatikal bahasa Kodi: Kajian tipologi sintaksis. Tesis. Denpasar: Program Pascasarjana Universitas Udayana.

Susandhika, I G.N., I K.D. Laksana dan I N. Suparwa. (2016). Fungsi, kategori, dan peran sintaksis dalam Talk Show "Indonesia Lawyers Club" di TV One. Jurnal LINGUISTIKA, Maret 2016, Vol. 23. No. 44.

Trask, R. I. (1996). A dictionary of grammatical terms in linguistics. England: Brighton.

Umiyati dan Kosmas. (2015). The inflectional phrase in Manggarai language. JURNAL TUTUR. Vol.1(2), Agustus 2015. ISSN 2442-3475.

Van Valin, R.D. \& R.J. Lapola. (1999). Syntax, structure, meaning and function. Cambridge: Cambridge University Press.

Van Valin, R.D. Jr. (2005). Exploring the syntax-semantics interface. Cambridge: Cambridge University Press.

Verhaar, J.W.M. (1983). Pengantar linguistik. Yogyakarta: Gadjah Mada University. 
. (2006). Asas-Asas linguistik umum. Yogyakarta: Gadjah Mada University.

. (1996). Asas-asas linguistik umum. Yogyakarta: Gadjah Mada University.Vol. 2. Mei $2008 \mathrm{Na} .1$.

Winahyu, S.K. (2011). Argumen dalam teks opini majalah Tempo, Tesis. Depok: Fakultas Ilmu Pengetahuan Budaya, Program Studi Linguistik, Universitas Indonesia. 